\title{
Lipaemia Retinalis in Untreated Diabetes Mellitus
}

\author{
W. M. FYFE, MARGARET S. HALL, and JANET W. SCOTT \\ From the Paediatric Unit and the Clinical Biochemistry Department, Stobhill General Hospital, Glasgow
}

\begin{abstract}
Fyfe, W. M., Hall, Margaret S., and Scott, Janet W. (1970). Archives of Disease in Childhood, 45, 84 Lipaemia retinalis in untreated diabetes mellitus. A 6-year-old girl developed diabetes mellitus, with marked hyperlipaemia and lipaemic retinalis, both of which rapidly cleared after insulin treatment. Biochemical studies led to the conclusion that dietary fat was the chief source of the excess triglyceride in the blood.
\end{abstract}

When hyperlipidaemia occurs in the untreated or poorly controlled diabetic the serum lipid levels are usually only moderately increased. Occasionally, however, the serum lipid levels are markedly increased, the serum is turbid, and lipaemia retinalis or eruptive xanthomata may be associated findings (Hamwi et al., 1962; Shipp, Wood, and Marble, 1964; Bagdade, Porte, and Bierman, 1967). This lipaemic syndrome usually occurs in insulin-dependent diabetic patients whose diabetes is poorly controlled, who have chronic insulin insufficiency, and who are symptomatic for long periods (Bagdade et al., 1967); it is unusual in a child with untreated diabetes. We describe here a girl of 6 years admitted in diabetic coma who had conspicuous hyperlipaemia and lipaemia retinalis. With control of her diabetes the serum lipid levels gradually returned to normal.

\section{Case Report}

A girl born in February 1960 was well until the age of 6 in February 1966, when she had measles. After this illness her appetite increased but despite this she lost weight; in addition she became increasingly listless and developed nocturia. In June 1966, she had tonsillitis treated with penicillin. By the end of June 1966, she was extremely weak, had polydipsia and polyuria, and was constipated. On 3 July 1966, she developed hyperpnoea. In the early morning of 4 July 1966, she had severe abdominal pain, and later that morning she became unconscious.

On admission to hospital on 4 July 1966, she was thin, dehydrated, and in coma. Her temperature was $37 \cdot 8^{\circ} \mathrm{C}$., heart rate $138 /$ minute, respiratory rate 42 / minute with hyperpnoea, and blood pressure $90 / 65 \mathrm{~mm}$. $\mathrm{Hg}$. Her abdomen was distended and tense. The appearance of her ocular fundi was typical of lipaemia

Received 2 June 1969. retinalis. No xanthomata were present. Hepatomegalyş with the liver edge four fingerbreadths below the costaq9 margin, was detected a few days after admission, when the abdominal distension had decreased sufficiently to permit palpation of the liver edge. The spleen was not palpable.

The serum of the blood sample obtained at the time of her admission to hospital looked like thick creamp analysis gave:-sugar $504 \mathrm{mg} . / 100 \mathrm{ml}$., urea $56 \mathrm{mg} . \mathrm{F}^{\circ}$ $100 \mathrm{ml}$., chloride $70 \mathrm{mEq} / \mathrm{l}$, sodium $100 \mathrm{mEg} / \mathrm{l}_{\infty}$ potassium $3.4 \mathrm{mEq} / 1$, triglycerides $11,520 \mathrm{mg} .100$ 유응 (normal 40-125), total cholesterol $1680 \mathrm{mg} . / 100 \mathrm{~m}$ (normal 125-250), free cholesterol $830 \mathrm{mg} .100$ 审。 (normal $20 \%-40 \%$ of total cholesterol), ester cholestero $850 \mathrm{mg} . / 100 \mathrm{ml}$. (normal $60 \%-80 \%$ of total cholesterol $\frac{}{\sigma}$ phospholipids $1375 \mathrm{mg} . / 100 \mathrm{ml}$. (normal 150-275) and free fatty acids $1500 \mu$ mole/l. (normal 230-380).

Paper electrophoresis of this serum and subsequent staining of the strip with Sudan black showed that the normal lipoprotein pattern was replaced by a single broad band extending from the origin to a position in front of the $a_{2}$-globulin.

The serum triglyceride was estimated by the method of Van Handel and Zilversmit (1957). The serum fres and ester cholesterol and the serum phospholipids wereestimated by methods quoted by Varley (1962). The serum free fatty acids were estimated by the method of Anstall and Trujillo (1965). Paper electrophoresis was carried out according to the method quoted by
Smith (1960).

Micro-Astrup analysis of capillary blood obtaine at the time of admission gave the following results $\mathrm{pH} 7 \cdot 05, \mathrm{PCO}_{2} 18 \mathrm{~mm}$. $\mathrm{Hg}$, standard bicarbonatĩ $8 \mathrm{mEq} / \mathrm{l}$., base excess minus $23 \mathrm{mEq} / \mathrm{l}$. Glycosuria an\& ketonuria were present.

She made a satisfactory response to treatment, and good control of her diabetes was established. Hef insulin requirement decreased during the first 4 weels of treatment and from the beginning of August $196 \%$ until the beginning of November 1966 she was mains tained on 4 or 6 units insulin zinc suspension (lente) daily. During the first 2 weeks of November $1966 \mathrm{O}$ 


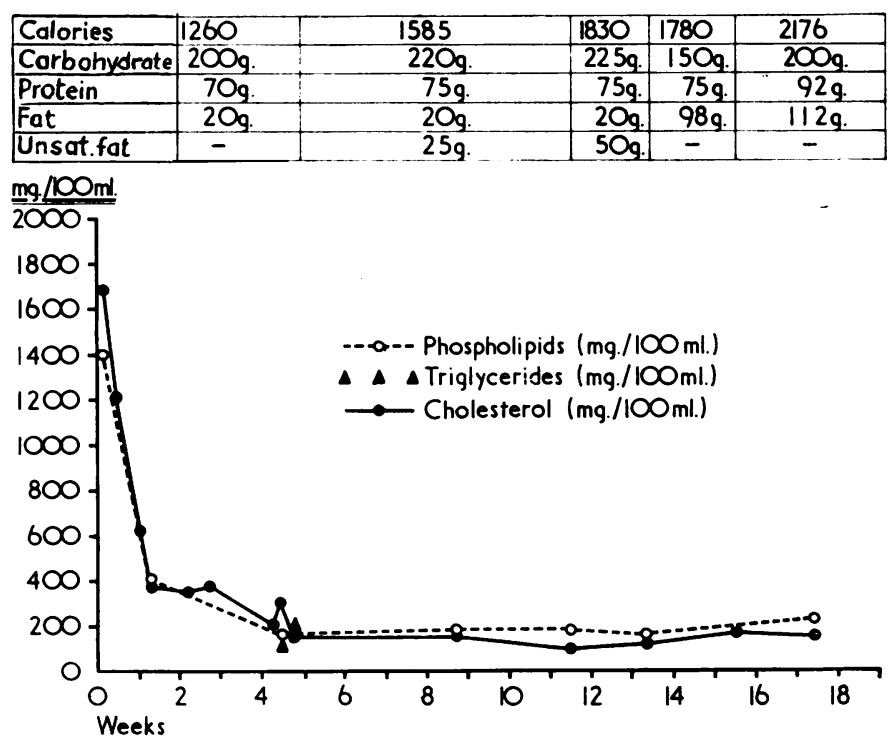

FIG.-Serum lipid levels during the first 18 weeks of treatment.

her insulin requirement increased to 18 units insulin zinc suspension (lente), and since then has remained at about this level.

The composition of the diets given during the first 18 weeks of treatment and the serum lipid levels during this period are shown in the Fig. During the first week of treatment the only fat in her diet was contained in one pint $(600 \mathrm{ml}$.) or less of skimmed milk, and for the next 26 days her diet contained $20 \mathrm{~g}$. fat. By the end of the first week of treatment the lipaemia retinalis was no longer present. The serum triglycerides were not estimated after the initial measurements until 4 weeks after the start of treatment when the level was within the normal range. After 18 days' treatment the serum cholesterol and phospholipids were still slightly raised, but after 4 weeks' treatment they also had fallen to within the normal range.

With the return of the serum lipid levels to normal the fat content of the diet was increased by the addition of $25 \mathrm{~g}$. and later $50 \mathrm{~g}$. unsaturated fat, using corn oil margarine as the source of this unsaturated fat. The serum cholesterol and phospholipid levels remained normal on these diets, and this led to a trial of diets in which all the fat was animal fat. A diet containing $98 \mathrm{~g}$. fat was given for 2 weeks, and then the fat content was increased to $112 \mathrm{~g}$. for the next 4 weeks. After 2 weeks on the diet containing $112 \mathrm{~g}$. fat the serum cholesterol was $175 \mathrm{mg} . / 100 \mathrm{ml}$., phospholipids $230 \mathrm{mg} . / 100 \mathrm{ml}$., and triglycerides $142 \mathrm{mg} . / 100 \mathrm{ml}$. A high fat diet, therefore, did not cause a recurrence of hyperlipaemia when the diabetes was adequately controlled with insulin therapy. Since mid-November 1966 the fat content of her diet has been about $90 \mathrm{~g}$., and on this diet the serum cholesterol and phospholipids have remained within the normal range. The serum triglycerides have not been estimated since November 1966.

\section{Family History}

There was no family history of diabetes mellitus. Both her parents and her 16-year-old brother were well. Her 11-year-old sister had coeliac disease and also hypertrophy of her left arm and left leg, associated when she was younger with an extensive naevus which had faded. Both parents and her brother and sister had normal serum cholesterol and phospholipid levels (Table). Their serum triglyceride levels were not estimated.

TABLE

Serum Lipids of Family

\begin{tabular}{l|c|c|c|c}
\hline & $\begin{array}{c}\text { Phospho- } \\
\text { lipids } \\
\text { (mg.P } \times 25) \\
(\mathrm{mg} / 100 \mathrm{ml} .)\end{array}$ & $\begin{array}{c}\text { Cholesterol } \\
\text { Total } \\
(\mathrm{mg} . / 100 \mathrm{ml} .)\end{array}$ & $\begin{array}{c}\text { Free } \\
(\mathrm{mg} . / 100 \mathrm{ml} .)\end{array}$ & $\begin{array}{c}\text { Ester } \\
(\mathrm{mg} . / 100 \mathrm{ml} .)\end{array}$ \\
\hline $\begin{array}{l}\text { Father } \\
\text { Mother }\end{array}$ & 280 & 190 & 52 & 138 \\
Brother & 195 & 148 & 48 & 100 \\
Sister & 200 & 170 & 51 & 119 \\
& 230 & 166 & 50 & 116 \\
\hline
\end{tabular}

\section{Discussion}

When hyperlipidaemia occurs in the uncontrolled diabetic, most of the lipid which accumulates in the blood is triglyceride. It appears that increased hepatic synthesis of triglyceride, increased dietary 
intake of triglyceride, and delayed clearance of triglyceride from the blood may all play a part in causing this hypertriglyceridaemia.

In uncontrolled diabetes increased mobilization of free fatty acids from adipose tissue raises the blood level of free fatty acids, and there is considerable evidence that this promotes increased hepatic synthesis of triglyceride (Steinberg, 1963).

The increased appetite so characteristic of uncontrolled diabetes is likely to lead to an increased intake of fat in the diet.

Delayed clearance of triglyceride from the blood could be caused by low tissue lipoprotein lipase activity, but the evidence about this is conflicting. Subnormal post-heparin lipolytic activity has been found in patients with diabetic hyperlipaemia before insulin therapy (Bagdade et al., 1967) and in insulindependent diabetics 48 hours after insulin withdrawal (Bagdade, Porte, and Bierman, 1968), but normal post-heparin lipolytic activity has also been found in diabetic patients with and without hyperlipaemia (Jones, Plotkin, and Arky, 1966). However, in any condition, such as diabetes, in which levels of endogenous triglyceride are raised the clearing of dietary fat is known to be impaired, even though post-heparin lipolytic activity is normal (Fredrickson, Ono, and Davis, 1963; Fredrickson and Lees, 1965).

While both triglyceride synthesized in the liver and dietary triglyceride contribute to the hypertriglyceridaemia the proportion from each of these sources varies. Some untreated diabetics have a marked increase in pre- $\beta$-lipoprotein in the plasma (Pantelakis et al., 1964), while others have a marked increase in chylomicrons in the plasma (Salt et al., 1960; Bagdade et al., 1967).

Bagdade et al. (1967) showed that in patients with diabetic hyperlipaemia isocaloric substitution of dietary carbohydrate for fat promptly lowered the plasma triglyceride level. Again rats made diabetic with alloxan became hyperlipaemic only if their diets contained fat; on fat-free diets plasma triglyceride levels in control and diabetic rats were virtually identical (Bierman, Amaral, and Belknap, 1966).

In most cases the serum lipid levels return to normal within 48 hours of starting insulin therapy (Hamwi et al., 1962). Pantelakis et al. (1964) described a group of diabetic children in whom pre- $\beta$-lipoproteinaemia present at the time of diagnosis persisted in spite of insulin therapy, but these workers were uncertain whether such children had an associated idiopathic hyperlipaemia, or whether the persistent accumulation of low density lipoprotein was an integral part of their diabetic state.
In the present case the serum lipid findings indi- $-\frac{}{5}$. cate that chylomicronaemia was almost certainly $\frac{\rho}{5}$ present. The relation between cholesterol and $\overline{0}$. phospholipids on the one hand and triglyceride $\Rightarrow$ on the other would fit the composition of chylo- $\stackrel{\vec{P}}{\rightarrow}$ microns, and so would the fact that $50 \%$ of the cholesterol was unesterified. This suggests that in our patient, as in those described by Bagdade $\frac{\bar{m}}{\frac{}{5}}$ et al. (1967), dietary fat was the chief source of the $\stackrel{\mathbb{\Phi}}{\Omega}$ excess triglyceride in the blood. The severity of the hyperlipaemia in the present case can possibly ${ }_{\vec{S}}$ be attributed to a high dietary fat intake during an? unusually long symptomatic and presumably $\vec{\omega}$ insulin-deficient period when clearance of dietary fat from the blood was impaired.

We are grateful to Dr. T. B. Begg and the staff of cr the MRC unit at the Western Infirmary, Glasgow, for the serum triglyceride estimations and also to Dr. J. W. $\odot$ Chambers for his advice in the management of this $\infty$ patient.

\section{REFERENCES}

Anstall, H. B., and Trujillo, J. M. (1965). Determination of free $T$ fatty acids in plasma by a colorimetric procedure: an appraisal $\frac{D}{O}$ of the method and comparison with other technics. Clinical Chemistry, 11, 741.

Bagdade, J. D., Porte, D., Jr., and Bierman, E. L. (1967). Diabetic lipemia. A form of acquired fat-induced lipemia. New England fournal of Medicine, 276, 427.

,-- , and - (1968). Acute insulin withdrawal and regulation of plasma triglyceride removal in diabetic subjecto Diabetes, $17,127$.

Bierman, E. L., Amaral, J. A. P., and Belknap, B. H. (1966). Hype्दु lipemia and diabetes mellitus. ibid., 15, 675.

Fredrickson, D. S., and Lees, R. S. (1965). A system for phenotyping hyperlipoproteinemia. Circulation, 31, 321.

-, Ono, K., and Davis, L. L. (1963). Lipolytic activity of post-heparin plasma in hyperglyceridemia. Fournal of Lipid Research, 4, 24.

Hamwi, G. J., Garcia, O., Kruger, F. A., Gwinup, G., and Cornwell, $\overrightarrow{\bar{O}}$ D. G. (1962). Hyperlipidemia in uncontrolled diabetes. Metabolism: Clinical and Experimental, 11, 850.

Jones, D. P., Plotkin, G. R., and Arky, R. A. (1966). Lipoprotein lipase activity in patients with diabetes mellitus, with and without hyperlipemia. Diabetes, 15, 565.

Pantelakis, S. N., Fosbrooke, A. S., Lloyd, J. K., and Wolff, O. H. ָి (1964). The nature and occurrence of pre-beta-lipoprotein in diabetic children and pregnant women. ibid., 13, 153.

Salt, H. B., Wolff, O. H., Nestadt, A., and Lloyd, J. K. (1960). Control of lipaemia in children with diabetes mellitus. The role of insulin and the effects of a diet rich in unsaturated fatty acids. Lancet, $1,71$.

Shipp, J. C., Wood, F. C., Jr., and Marble, A. (1964). Hyperlipemia following sulfonylurea therapy in young diabetics. 음 fournal of the American Medical Association, 188, 468.

Smith, I. (1960). Chromatographic and Electrophoretic Techniques $\frac{D}{O}$ Vol. 2. Heinemann, London.

Steinberg, D. (1963). Fatty acid mobilization: mechanisms of regulation and metabolic consequences. Biochemical Society $\mathrm{N}$ Symposia, 24, 111.

Van Handel, E., and Zilversmit, D. B. (1957). Micromethod for the direct determination of serum triglycerides. Fournal of $\mathrm{N}$
Laboratory, and Clinical Medicine, 50,152 .

Varley, H. (1962). Practical Clinical Biochemistry. 3rd. ed. Heinemann, London.

Correspondence to Dr. W. M. Fyfe, Paediatric $\stackrel{\mathbb{\infty}}{+}$ Unit, Stobhill General Hospital, Glasgow N.1. 